\title{
Health-related quality of life among people living with type 2 diabetes: a community based cross-sectional study in rural Nepal
}

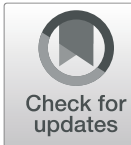

\author{
Sailendra Thapa ${ }^{1 *}$ (D), Prajjwal Pyakurel ${ }^{2}$, Dharani Dhar Baral ${ }^{2}$ and Nilambar Jha ${ }^{2}$
}

\begin{abstract}
Background: Diabetes as being a chronic disease with a number of complications deteriorates the quality of life among the people with type 2 diabetes. Health related quality of life is widely used as an important health outcome measure worldwide. This study assessed the quality of life among the people living with type 2 diabetes in rural area of eastern Nepal.
\end{abstract}

Methods: A cross sectional study was conducted among type 2 diabetic patient of rural area of eastern Nepal. Pre-tested Nepali version of D-39 questionnaire was administered through face to face interview to assess the quality of life. Door to door visit was done to identify all the type 2 diabetic patients residing in Baniyani village. Data was entered in Micro-soft excel 2007 and further processed in SPSS v.11.5 for analysis.

Results: Highest quality of life mean (SD) score was in social burden domain (56.26 \pm 12.07$)$, followed by sexual functioning domain (54.35 \pm 9.47 ), Anxiety and worry domain ( $54.33 \pm 7.76$ ), energy and mobility domain ( $51.46 \pm 8.73$ ) and diabetes control domain (50.08 \pm 10.84). There was negative correlation between age and domains sexual functioning $(p=0.001)$ and energy and mobility $(p=0.002)$. In bivariate analysis, there was significance difference by sex in sexual functioning $(p=$ $0.002)$, educational status in diabetes control $(p=0.021)$, smoking habit in energy and mobility $(p=0.038)$, duration of disease in diabetes control $(p=0.002)$ and sexual functioning $(p=0.001)$, presence of co-morbidity in social burden ( $p=$ $0.034)$ and family history of diabetes in anxiety and worry $(p=0.042)$.

Conclusion: Increasing age affects sexual life and mobility of the type 2 diabetic patient. The domain sexual functioning is difference by sex and presence of co-morbidity. Similarly, domain diabetic control is affected by duration of disease and educational status of the patient. And having family history of diabetes affects the mental state of the type 2 diabetic patient.

Keywords: Quality of life, Type 2 diabetes, Rural area, D-39 questionnaire

\section{Background}

World Health Organization (WHO) recognizes diabetes as one of the most important cause for preventable mortality and morbidity among non-communicable diseases worldwide. In 2018 there are more than 500 million people living with type 2 diabetes (T2DM) worldwide [1]. Change in lifestyle and behavioral factors have greater impact over increasing trend of diabetes worldwide $[2,3]$. The estimated prevalence of T2DM in Nepal in 2015 was 8.4\% [4] and in

\footnotetext{
* Correspondence: thapasailen@gmail.com

1 Department of Public Health, Manmohan Memorial Institute of Health

Sciences, Kathmandu 44614, Nepal

Full list of author information is available at the end of the article
}

2017 it was found to be $11.7 \%$ [5]. The burden of T2DM is increasing steadily in low income countries due to adoption of unhealthy lifestyle. T2DM is no more the disease of affluence as the prevalence of diabetes is also increasing in poorer section of community.

Diabetes being a chronic disease with number of complications deteriorates the quality of life among the people with T2DM. Quality of life is widely used as an important health outcome measure worldwide [6]. QOL refers to the physical, psychological, and social domains of health that are influenced by a person's experiences, beliefs, expectations, and perceptions; therefore, health care providers

(c) The Author(s). 2019 Open Access This article is distributed under the terms of the Creative Commons Attribution 4.0 International License (http://creativecommons.org/licenses/by/4.0/), which permits unrestricted use, distribution, and reproduction in any medium, provided you give appropriate credit to the original author(s) and the source, provide a link to the Creative Commons license, and indicate if changes were made. The Creative Commons Public Domain Dedication waiver (http://creativecommons.org/publicdomain/zero/1.0/) applies to the data made available in this article, unless otherwise stated. 
should strive to understand the physical, emotional, and social impacts of chronic disease such as diabetes [7, 8].

Quality of life is a subjective measurement as many of its dimensions cannot be measured directly because it is related to perceived impact by the people over their life. It always try to quantify the consequences and self-perception of disease $[9,10]$. Type 2 diabetic individuals are known to have lower quality of life and more depressive symptomatology than those without T2DM. It is accompanied by a marked reduction in patient's quality of life and leads to higher disability adjusted life years than most diseases. The effects of T2DM include long term damage, dysfunction and failure of various organs. T2DM accounts for the majority (90\%) of all diabetes case [11].

T2DM related complications are major causes of morbidity and mortality and have significant impact on the patient's quality of life and productivity [12]. It is predicted that people with T2DM of Nepal have relatively reduced quality of life [11]. People with T2DM often feel challenged by their disease related features and complications and its day to day management demands. T2DM affects the health related quality of life through macro vascular complications associated non-vascular co-morbidity and also by total burden of disease [13]. Very few hospital based studies has been conducted to understand the quality of life among T2DM patient of Nepal $[11,13]$. These studies revel poor health outcome largely affecting the quality of life of T2DM patients. Quality of life of T2DM patient in Nepal with less access to health care settings is still unknown. Hence, despite of having good assess to specialized health care in urban areas the T2DM patients shows lower quality of life, it shows an immense urgency of assessing in areas with less assess of health care. WHOBREF tool is widely used tool to assess the quality of life but D-39 questionnaire, which is disease (T2DM) specific, used to assess the quality of life of T2DM patients. As D39 is diabetes specific questionnaire to assess the quality of life, it gives more precise result about the dimension of quality of life that is mostly affected due to presence the condition. This questionnaire is widely used among Americans and Europeans [14, 15]. Assessing quality of life among T2DM patient helps to provide proper care and management of complications in clinical as well as community level. Hence this study attempts to revel the quality of life of T2DM patient at community level.

\section{Methodology}

Community based cross Sectional study was conducted in Baniyani Village Development Committee (VDC) of Jhapa district of eastern Nepal. Door to door visit was done with the help of female community health volunteers (FCHVs) to identify diabetic patients. Those patients, who were not available during first visit, were subsequently followed for second and third times.

A pre-tested semi-structured questionnaire was used to elicit information on socio-demographic characteristics and disease profile. D-39 questionnaire was used to assess the quality of life among T2DM patient [15]. D39 questionnaire consists of 39 items and 5 domains (Diabetes control, Anxiety and worry, Social burden, Sexual functioning and Energy and mobility). The questionnaire showed good internal consistency during pretesting with Cronbach alpha of 0.78. The questionnaire was translated into Nepali language and pretested among the 20 diabetic patients. Face and content validity was then established by consulting experts and searching the available literature. The obtained score was transferred to $0-100$ scale according to previous literature [15] for the purpose of comparison. Collected data was coded and entered in Micro-soft excel 2007 and analysis was done in Statistical Package for Social Science (SPSS v.11.5). Data are presented as frequency, percentage, mean and standard deviation. Pearson's correlation and analysis of variance (ANOVA) test were used to analyze the relation between independent factors and domains of quality of life.

All those diabetic patients who were more than 20 years and been diagnosed with diabetes with more than 6 months were included in this study. Institutional Review Committee (IRC) of B. P Koirala Institute of Health Sciences (BPKIHS), Dharan, Nepal provided Ethical Clearance. Informed written consent was taken from each study participant.

\section{Results}

The study has identified 102 T2DM patients aged over 20 years and residing in Baniyani Village Development Committee (VDC) of Jhapa district of Eastern Nepal.

Table 1 [3] represents the socio-demographic characteristics of the respondents. Majority (58.8\%) of the respondents were above 50 years of age and more than half (59.8\%) of the respondents were male. About $28.4 \%$ of the participants were alcohol consumer. The jad/ rakshi (nepali home-made alcoholic drink) was the most (19.6\%) consumed alcoholic drink followed by beer (12.7\%) and vodka (4.9\%).

Table 2 [3] shows the disease profile of the participants. Less than half (31.4\%) of the respondents reported having diabetes for more than 5 years. The hypertension was the mostly $(46.1 \%)$ reported co-morbidity followed by gastritis $(8.8 \%)$.More than half $(58.8 \%)$ of the respondents were suffering from complications due to diabetes. The respondents reported retinopathy as mostly (37.3\%) reported complication.

Table 3 represents descriptive statistics of the domains of quality of life of D-39. The cronbach's alpha coefficient 
Table 1 Socio demographic characteristics of the respondents

\begin{tabular}{|c|c|c|c|}
\hline Characteristics & Categories & $\begin{array}{l}\text { Frequency } \\
n=102\end{array}$ & $\begin{array}{l}\text { Percentage } \\
(\%)\end{array}$ \\
\hline \multirow[t]{2}{*}{$\overline{\text { Age }}$} & $<50$ years & 42 & 41.2 \\
\hline & $\geq 50$ years & 60 & 58.8 \\
\hline \multicolumn{4}{|c|}{ Mean age $=55.23 \pm 12.39$ years } \\
\hline \multirow[t]{2}{*}{ Sex } & Male & 61 & 59.8 \\
\hline & Female & 41 & 40.2 \\
\hline \multirow[t]{4}{*}{ Ethnicity } & $\begin{array}{l}\text { Dalit/ } \\
\text { Janajati }\end{array}$ & 24 & 23.5 \\
\hline & Madeshi & 6 & 5.9 \\
\hline & Muslim & 11 & 10.8 \\
\hline & $\begin{array}{l}\text { Brahmin/ } \\
\text { Chhetry }\end{array}$ & 61 & 59.8 \\
\hline \multirow[t]{2}{*}{ Family type } & Single & 45 & 44.1 \\
\hline & Joint & 57 & 55.9 \\
\hline \multirow[t]{2}{*}{ Marital status } & Married & 100 & 98 \\
\hline & Widow & 2 & 2 \\
\hline \multirow[t]{4}{*}{ Educational status } & Literate & 79 & 77.5 \\
\hline & - Formal & 54 & 68.4 \\
\hline & - Informal & 25 & 31.6 \\
\hline & Illiterate & 23 & 22.5 \\
\hline \multirow[t]{2}{*}{ Smoking habit } & Yes & 19 & 18.6 \\
\hline & No & 83 & 81.4 \\
\hline \multirow[t]{2}{*}{ Alcohol consumption } & Yes & 29 & 28.4 \\
\hline & No & 73 & 71.6 \\
\hline \multirow{4}{*}{$\begin{array}{l}\text { Type of alcohol } \\
\text { consumption }(n=29)\end{array}$} & Beer & 13 & 12.7 \\
\hline & Wine & 1 & 1 \\
\hline & Vodka & 5 & 4.9 \\
\hline & Jad/rakshi & 20 & 19.6 \\
\hline
\end{tabular}

${ }^{a}$ multiple response

ranged from 0.63 (energy and mobility) to 0.80 (Sexual functioning). This study found the highest mean (SD) score was in social burden domain (56.26 \pm 12.07$)$, followed by sexual functioning domain $(54.35 \pm 9.47)$, Anxiety and worry domain (54.33 \pm 7.76 ), energy and mobility domain $(51.46 \pm 8.73)$ and diabetes control domain (50.08 \pm 10.84$)$.

Table 4 shows association between independent variables and domains of quality of life. Domains sexual functioning $(p=0.001)$ and energy and mobility $(p=$ 0.002 ) were negatively correlated with age. This study found significance difference by sex in sexual functioning $(p=0.002)$, educational status in diabetes control $(p=0.021)$, smoking habit in energy and mobility $(p=$ $0.038)$, duration of disease in diabetes control $(p=0.002)$ and sexual functioning $(p=0.001)$, presence of co-morbidity in social burden $(p=0.034)$ and family history of diabetes in anxiety and worry $(p=0.042)$.
Table 2 Disease profile of the respondents

\begin{tabular}{|c|c|c|c|}
\hline Characteristics & Categories & $\begin{array}{l}\text { Frequency } \\
n=102\end{array}$ & $\begin{array}{l}\text { Percentage } \\
(\%)\end{array}$ \\
\hline \multirow[t]{2}{*}{ Duration of disease } & $<5$ years & 70 & 68.6 \\
\hline & $\geq 5$ years & 32 & 31.4 \\
\hline \multirow{2}{*}{$\begin{array}{l}\text { Presence of } \\
\text { co morbidity }\end{array}$} & Yes & 60 & 58.8 \\
\hline & No & 42 & 41.2 \\
\hline \multirow{9}{*}{$\begin{array}{l}\text { a Type of } \\
\text { co-morbidity } \\
(n=60)\end{array}$} & Hypertension & 47 & 46.1 \\
\hline & Depression & 1 & 1 \\
\hline & Heart disease & 1 & 1 \\
\hline & Dental caries & 1 & 1 \\
\hline & Arthritis & 1 & 1 \\
\hline & Asthma & 3 & 2.9 \\
\hline & Hydrocele & 1 & 1 \\
\hline & Skin disease & 2 & 2 \\
\hline & Gastritis & 9 & 8.8 \\
\hline \multirow{2}{*}{$\begin{array}{l}\text { Presence of } \\
\text { complication }\end{array}$} & Yes & 60 & 58.8 \\
\hline & No & 42 & 41.2 \\
\hline \multirow{5}{*}{$\begin{array}{l}{ }^{a} \text { Type of } \\
\text { complications } \\
(n=60)\end{array}$} & $\begin{array}{l}\text { Cardio vascular } \\
\text { disease }\end{array}$ & 3 & 2.9 \\
\hline & Neuropathy & 8 & 7.8 \\
\hline & Nephropathy & 2 & 2 \\
\hline & Retinopathy & 38 & 37.3 \\
\hline & Foot damage & 31 & 30.4 \\
\hline \multirow{2}{*}{$\begin{array}{l}\text { Family history } \\
\text { of diabetes }\end{array}$} & Yes & 41 & 40.2 \\
\hline & No & 61 & 59.8 \\
\hline
\end{tabular}

${ }^{a}$ multiple response

\section{Discussion}

This study assessed the dimensions in which the quality of life of the T2DM residing in Baniyani VDC was affected.

The result revealed various dimension of quality of life of the diabetic patient that is affected. Highest score of quality of life was found in social burden dimension. It indicates that diabetic patients are getting good support

Table 3 Descriptive statistics of the D-39 domains

\begin{tabular}{lllllll}
\hline $\begin{array}{l}\text { D-39 } \\
\text { Domains }\end{array}$ & $\begin{array}{l}\text { No. of } \\
\text { items }\end{array}$ & $\begin{array}{l}\text { Cronbach } \\
\text { Alpha }\end{array}$ & Mean & SD & Minimum & Maximum \\
\hline $\begin{array}{l}\text { Diabetes } \\
\text { control }\end{array}$ & 12 & 0.679 & 50.08 & 10.8 & 27.54 & 83.46 \\
$\begin{array}{l}\text { Anxiety and } \\
\text { worry }\end{array}$ & 4 & 0.759 & 54.33 & 7.76 & 37.00 & 72.53 \\
$\begin{array}{l}\text { Social } \\
\text { burden }\end{array}$ & 5 & 0.736 & 56.26 & 12.07 & 28.34 & 87.00 \\
$\begin{array}{l}\text { Sexual } \\
\text { functioning }\end{array}$ & 3 & 0.801 & 54.35 & 9.47 & 33.67 & 75.87 \\
$\begin{array}{l}\text { Energy and } \\
\text { mobility }\end{array}$ & 15 & 0.635 & 51.46 & 8.7 & 32.00 & 85.56 \\
\begin{tabular}{l} 
Total score \\
\hline
\end{tabular} & 39 & 0.762 & 53.49 & 11.2 & 35.76 & 76.48 \\
\hline
\end{tabular}


Table 4 Bivariate association between independent variables and quality of life domains

\begin{tabular}{|c|c|c|c|c|c|c|c|}
\hline Characteristics & Category & $\begin{array}{l}\text { Diabetes control } \\
{[\text { Mean (SD)] }}\end{array}$ & $\begin{array}{l}\text { Anxiety and worry } \\
{[\text { Mean (SD)] }}\end{array}$ & $\begin{array}{l}\text { Social burden } \\
{[\text { Mean (SD)] }}\end{array}$ & $\begin{array}{l}\text { Sexual functioning } \\
{[\text { Mean (SD)] }}\end{array}$ & $\begin{array}{l}\text { Energy and } \\
\text { mobility [Mean } \\
\text { (SD)] }\end{array}$ & $\begin{array}{l}\text { Overall QoL } \\
\text { [Mean (SD)] }\end{array}$ \\
\hline $\mathrm{Age}^{\mathrm{a}}$ & & 0.170 & 0.063 & 0.063 & -0.422 & -0.306 & 0.170 \\
\hline$P$-value & & 0.874 & 0.532 & 0.388 & 0.001 & 0.002 & 0.073 \\
\hline \multirow[t]{2}{*}{ Sex } & Male & $52.08(11.26)$ & $51.21(12.69)$ & $50.04(9.26)$ & $52.46(11.42)$ & $54.36(13.02)$ & $52.53(10.33)$ \\
\hline & Female & $50.40(10.61)$ & $52.63(11.53)$ & $53.54(10.05)$ & $51.11(9.44)$ & $50.42(11.03)$ & $51.48(12.42)$ \\
\hline$P$-value & & 0.543 & 0.086 & 0.342 & 0.002 & 0.634 & 0.743 \\
\hline \multirow[t]{4}{*}{ Ethnicity } & Dalit/Janajati & $50.42(9.28)$ & $52.83(10.63)$ & $56.33(8.68)$ & $53.06(11.54)$ & $51.22(10.34)$ & $54.38(10.06)$ \\
\hline & Madeshi & $51.13(7.42)$ & $53.54(9.56)$ & $55.42(12.34)$ & $50.28(9.84)$ & $54.79(12.02)$ & $49.64(12.33)$ \\
\hline & Muslim & $54.23(11.64)$ & $52.12(11.62)$ & $50.12(9.63)$ & $51.62(12.43)$ & $53.11(10.44)$ & $52.73(9.23)$ \\
\hline & $\begin{array}{l}\text { Brahmin/ } \\
\text { Chhetry }\end{array}$ & $53.22(10.04)$ & $54.67(8.45)$ & $51.62(11.24)$ & $52.43(14.56)$ & $50.45(11.84)$ & $53.61(8.86)$ \\
\hline$P$-value & & 0.726 & 0.541 & 0.823 & 0.431 & 0.562 & 0.312 \\
\hline \multirow[t]{2}{*}{ Family Type } & Single & $57.06(5.66)$ & $53.45(6.37)$ & $51.36(11.41)$ & $53.51(8.62)$ & $55.97(10.36)$ & $54.21(8.33)$ \\
\hline & Joint & $54.42(8.96)$ & $56.21(10.46)$ & $52.13(12.44)$ & $57.62(6.12)$ & $52.63(11.25)$ & 54.37 (6.39) \\
\hline$P$-value & & 0.063 & 0.126 & 0.078 & 0.643 & 0.563 & 0.052 \\
\hline \multirow[t]{3}{*}{$\begin{array}{l}\text { Socio-economic } \\
\text { status }\end{array}$} & $\begin{array}{l}\text { Upper/Upper } \\
\text { middle }\end{array}$ & $57.42(9.12)$ & $53.48(8.44)$ & $56.44(7.23)$ & $59.36(9.87)$ & $57.56(11.02)$ & $56.12(12.93)$ \\
\hline & $\begin{array}{l}\text { Middle/ } \\
\text { lower middle }\end{array}$ & $54.21(10.48)$ & $55.87(10.36)$ & $57.76(11.14)$ & $58.78(14.54)$ & $56.45(11.07)$ & $55.39(9.63)$ \\
\hline & $\begin{array}{l}\text { Lower/upper } \\
\text { lower }\end{array}$ & $51.62(8.41)$ & $50.13(9.36)$ & $58.37(9.87)$ & $56.47(11.47)$ & $53.22(7.63)$ & $49.35(12.67)$ \\
\hline$P$-value & & 0.816 & 0.236 & 0.479 & 0.973 & 0.643 & 0.622 \\
\hline \multirow{2}{*}{$\begin{array}{l}\text { Educational } \\
\text { status }\end{array}$} & Literate & $55.62(7.66)$ & $58.63(9.47)$ & $58.78(11.36)$ & $53.24(12.49)$ & $51.33(7.36)$ & $49.35(12.67)$ \\
\hline & Illiterate & $57.23(6.83)$ & $55.44(7.43)$ & $58.63(12.36)$ & $50.41(9.57)$ & $51.18(7.72)$ & $53.56(8.31)$ \\
\hline$P$-value & & 0.021 & 0.073 & 0.057 & 0.082 & 0.078 & 0.067 \\
\hline \multirow[t]{2}{*}{ Smoking habit } & Yes & $53.79(12.43)$ & $58.72(11.21)$ & $53.46(15.78)$ & $50.44(13.61)$ & $52.47(9.35)$ & 55.87 (9.92) \\
\hline & No & $54.37(11.68)$ & $50.12(13.47)$ & $49.37(9.87)$ & $55.46(10.47)$ & $51.25(11.53)$ & $54.29(10.41)$ \\
\hline$P$-value & & 0.237 & 0.649 & 0.985 & 0.583 & 0.038 & 0.732 \\
\hline \multirow{2}{*}{$\begin{array}{l}\text { Alcohol } \\
\text { consumption }\end{array}$} & Yes & $58.47(8.63)$ & $51.06(9.31)$ & $54.75(6.72)$ & $50.08(7.31)$ & $55.74(10.44)$ & $48.35(11.25)$ \\
\hline & No & $53.67(12.31)$ & $57.58(11.04)$ & 49.08 (12.93) & $54.21(10.47)$ & $57.09(9.81)$ & $54.37(7.74)$ \\
\hline$P$-value & & 0.421 & 0.513 & 0.435 & 0.916 & 0.541 & 0.671 \\
\hline \multirow{2}{*}{$\begin{array}{l}\text { Duration of } \\
\text { disease }\end{array}$} & $<5$ years & $58.42(13.42)$ & $59.32(12.44)$ & $51.76(10.57)$ & 57.39 (15.09) & $50.07(14.11)$ & $57.23(10.73)$ \\
\hline & $\geq 5$ years & $50.51(7.83)$ & $48.63(9.43)$ & $54.03(12.09)$ & $53.02(11.72)$ & $54.44(10.66)$ & $53.03(9.13)$ \\
\hline$P$-value & & 0.002 & 0.078 & 0.063 & 0.001 & 0.088 & 0.059 \\
\hline \multirow{2}{*}{$\begin{array}{l}\text { Presence of } \\
\text { co-morbidity }\end{array}$} & Yes & $55.96(12.47)$ & $50.31(13.77)$ & $52.77(10.29)$ & $54.67(10.38)$ & $51.38(9.67)$ & $54.78(11.41)$ \\
\hline & No & $58.63(8.33)$ & $54.67(9.47)$ & $53.38(18.34)$ & 55.39 (15.09) & $56.74(11.38)$ & $48.43(12.07)$ \\
\hline$P$-value & & 0.042 & 0.057 & 0.034 & 0.051 & 0.073 & 0.081 \\
\hline \multirow{2}{*}{$\begin{array}{l}\text { Presence of } \\
\text { complication }\end{array}$} & Yes & $57.38(12.61)$ & $55.08(9.42)$ & $59.02(10.05)$ & $49.06(11.23)$ & 57.04 (15.68) & $50.78(13.47)$ \\
\hline & No & $54.14(14.33)$ & $53.81(9.37)$ & $51.21(8.53)$ & $50.51(9.59)$ & 55.09 (11.14) & $53.35(10.67)$ \\
\hline$P$-value & & 0.344 & 0.516 & 0.734 & 0.819 & 0.547 & 0.539 \\
\hline \multirow{2}{*}{$\begin{array}{l}\text { Family history } \\
\text { of diabetes }\end{array}$} & Yes & $55.79(7.04)$ & $51.72(12.54)$ & 55.37 (13.09) & $53.48(11.57)$ & $51.73(12.22)$ & $51.43(13.46)$ \\
\hline & No & $49.37(9.57)$ & $55.76(10.13)$ & $56.43(10.35)$ & $56.27(13.47)$ & $52.94(12.17)$ & $49.03(11.63)$ \\
\hline$P$-value & & 0.573 & 0.042 & 0.874 & 0.071 & 0.439 & 0.563 \\
\hline
\end{tabular}

aPearson's correlation 
in the society. Domain energy and mobility with least score was also found to be affected. It shows that respondents were feeling less energy affecting their daily life. Because of diabetes they were getting problem in walking and fulfilling their daily requirements. Similarly a study from Brazil and United States found contradicting result that the dimensions sexual functioning and diabetes control was greatly affected [10, 16]. But another study [17], shows that the dimension diabetes control is more affected than sexual functioning. Although both of the results have been supported by the study conducted in Nepal [11].

This study found a negative correlation of age with domains sexual functioning and energy and mobility. It describes that sexual life of a diabetic patient is affected with increasing age. Result revels that the sexual functioning of the participant is determined by their gender. Similar result has been demonstrated by the study conducted in Iran indicating the association of gender difference with quality of life [18].

This study found that educational status also affects their sugar level. This indicates that educational level enhances the skill of diabetic patient to bring their sugar level in control. Relationship between education and quality of life was demonstrated by study conducted in Turkey [19]. Dimensions sexual functioning and diabetes control were greatly affected by number of year they were diagnosed with diabetes. Complications associated with diabetes might have impact over the sexual life and create obstacles during it management. Contrarily, another study found relationship between duration of disease with energy and mobility [11].

Having co-morbidity is associated with social burden, affecting the social relationship within the community and thus the quality of life of the diabetic patient residing in eastern Nepal. Presence of co-morbidity may affect mobility of the diabetic patient which creates barrier in involving social functions and events. Previous study conducted in Mexico and South India found similar result [20, 21]. Association between family history of diabetes and the dimension anxiety and worry was found by this study. It indicates that those diabetic patients with family history were worried about the condition affecting the quality of life. Although this study did not find any relationship between quality of life and socio-economic status, study from refugee camps of Gaza strip found strong impact of economic status of the diabetic people over the quality of life [22]. Due to increased access of health care facility, free medication and consultation might have reduced the impact of economic status in management of diabetes in eastern Nepal.

This is perhaps the first community based study conducted in Nepal using diabetes-39 questionnaire in order to assess the quality of life of diabetic patient. The study is limited to a single VDC of eastern Nepal so, we suggest further studies including large sample size for better understanding of the dimensions of quality of life of diabetic patient.

\section{Conclusion}

This study found that with increasing age sexual life and mobility of the diabetic patient is also affected. The domain sexual functioning is difference by sex and having co-morbidity also have difference in their sexual life. Similarly, maintaining blood sugar level is affected by duration of disease and educational status of the patient. And having family history of diabetes affects the mental state of the diabetic patient. Hence it is needed to focus on screening program and diabetic education in community level in order to limit its complications and to increase the quality of life of type 2 diabetic patient.

\section{Abbreviations}

BPKIHS: BP Koirala Institute of Health Sciences; COHESION: Community Health System Innovation; FCHVs: Female Community Health Volunteers; IRC: Institutional Review Committee; PHCC: Primary Health Care Centre: VDC: Village Development Committee

\section{Acknowledgements \\ We would like to express our acknowledgement to School of Public Health and Community Medicine, BPKIHS, Community Health System Innovation (COHESION) project supported by Swiss Agency for Development and co- operation and Swiss National Science Foundation for their support. We would like to thank to all the participants, FCHVs and staffs of Baniyani Primary Health Care Center.}

\section{Authors' contributions}

ST, NJ, PP conceived the study design, ST and DDB coordinated for acquisition, analysis and interpretation of data. ST drafted the manuscript and NJ, DDB, PP critical revised the manuscript. All authors read and approved the final manuscript.

\section{Funding \\ Not applicable.}

Availability of data and materials

Entered data are available on request from the corresponding author.

\section{Ethics approval and consent to participate}

The Institutional Review Committee, B. P Koirala Institute of Health Sciences, reviewed and approved the study. Written informed consent was obtained from all the participants.

Consent for publication

Not applicable.

\section{Competing interests}

The authors declare that they have no competing interests.

\section{Author details}

${ }^{1}$ Department of Public Health, Manmohan Memorial Institute of Health Sciences, Kathmandu 44614, Nepal. ${ }^{2}$ School of Public Health and Community Medicine, BP Koirala Institute of Health Sciences, Dharan 56705, Nepal.

Received: 12 February 2019 Accepted: 15 August 2019

Published online: 27 August 2019

\section{References}

1. Kaiser AB, Zhang N, Der Pluijm WV. Global prevalence of type 2 diabetes over the next ten years (2018-2028). Diabetes. 2018;67:202 Supplement 1). 
2. Zimmet P, Alberti K, Shaw J. Global and societal implications of the diabetes epidemic. Nature. 2001;414(6865):782-7.

3. Thapa S, Jha N, Baral DD, Pyakurel P. Health care seeking behaviour among people living with Type-2 diabetes in rural area of eastern, Nepal. Int J Pub Health Safe. 2018;3:166.

4. Gyawali B, Sharma R, Neupane D, Mishra SR, van Teijlingen E, Kallestrup P. Prevalence of type 2 diabetes in Nepal: a systematic review and metaanalysis from 2000 to 2014. Global Health Action. 2015;8. https://doi.org/1 0.3402/gha.v3408.29088.

5. Gyawali B, Hansen MRH, Povlsen MB, Neupane D, Andersen PK, McLachlan CS. SandbÃ $k$ a, Vaidya a, Kallestrup P: awareness, prevalence, treatment, and control of type 2 diabetes in a semi-urban area of Nepal: findings from a cross-sectional study conducted as a part of COBIN-D trial. PLoS One. 2018; 13(11):e0206491.

6. Hand C. Measuring health-related quality of life in adults with chronic conditions in primary care settings: critical review of concepts and 3 tools. Can Fam Physician. 2016;62(7):e375-83.

7. Camacho F, Anderson R, Bell R, Goff D, Duren-Winfield V, Doss D, Balkrishnan R. Investigating correlates of health related quality of life in a low-income sample of patients with diabetes. Qual Life Res. 2002;11(8):783-96.

8. Al Hayek AA, Robert AA, Al Saeed A, Alzaid AA, Al Sabaan FS: Factors associated with health-related quality of life among Saudi patients with type 2 diabetes mellitus: a cross-sectional survey. Diabetes Metab J 2014, 38(3):220-229.

9. Holmes S. Assessing the quality of life-reality or impossible dream?: a discussion paper. Int J Nurs Stud. 2005:42(4):493-501.

10. de Queiroz FA, Pace AE, dos Santos CB. Cross-cultural adaptation and validation of the instrument Diabetes-39 (D-39): brazilian version for type 2 diabetes mellitus patients-stage 1. Revista latino-americana de enfermagem. 2009:17(5):708-15.

11. Mishra SR, Sharma A, Bhandari PM, Bhochhibhoya S, Thapa K. Depression and health-related quality of life among patients with type 2 diabetes mellitus: a cross-sectional study in Nepal. PLoS One. 2015;10(11):e0141385.

12. Ayele K, Tesfa B, Abebe L, Tilahun T, Girma E. Self care behavior among patients with diabetes in Harari, eastern Ethiopia: the health belief model perspective. PLoS One. 2012;7(4):e35515.

13. Mehta RK, Subedi S, Bohora S. Health related quality of life of diabetic patients visited in Koshi zonal hospital, Biratnanar. J Chitwan Medical College. 2015;4(3):13-6.

14. Khanna A, Bush AL, Swint JM, Peskin MF, Street RL, Naik AD. Hemoglobin A1c improvements and better diabetes-specific quality of life among participants completing diabetes self-management programs: a nested cohort study. Health Qual Life Outcomes. 2012;10(1):48.

15. Boyer JG, Earp JAL. The development of an instrument for assessing the quality of life of people with diabetes: Diabetes-39. Med Care. 1997;35:440-53.

16. Khanna A, Bush AL, Swint JM, Peskin MF, Street RL, Naik AD. Hemoglobin a 1c improvements and better diabetes-specific quality of life among participants completing diabetes self-management programs: a nested cohort study. Health Qual Life Outcomes. 2012;10(1):48.

17. Zulian LR, MAd S, Veras VS, Rodrigues FFL, Arrelias CCA, Zanetti ML. Quality of life in patients with diabetes using the diabetes 39 (D-39) instrument. Revista Gaúcha de Enfermagem. 2013;34(3):138-46.

18. Yekta Z, Pourali R, Ghasemi-rad M. Comparison of demographic and clinical characteristics influencing health-related quality of life in patients with diabetic foot ulcers and those without foot ulcers. Diabetes Metab Syndr Obes. 2011;4:393.

19. Äb E, Ãz E, Åžzhin M. The effect of depression on quality of life of patients with type II diabetes mellitus. Depress Anxiety. 2008;25(2):98-106.

20. López-Carmona JM, Rodriguez-Moctezuma R. Adaptación y validación del instrumento de calidad de vida Diabetes 39 en pacientes mexicanos con diabetes mellitus tipo 2. Salud pública de Mexico. 2006;48:200-11.

21. Prajapati $V B$, Blake R, Acharya LD, Seshadri S. Assessment of quality of life in type II diabetic patients using the modified diabetes quality of life (MDQoL)-17 questionnaire. Braz J Pharm Sci. 2017;53:4.

22. Eljedi A, Mikolajczyk RT, Kraemer A, Laaser U. Health-related quality of life in diabetic patients and controls without diabetes in refugee camps in the Gaza strip: a cross-sectional study. BMC Public Health. 2006;6(1):268.

\section{Publisher's Note}

Springer Nature remains neutral with regard to jurisdictional claims in published maps and institutional affiliations.

\section{Ready to submit your research? Choose BMC and benefit from}

- fast, convenient online submission

- thorough peer review by experienced researchers in your field

- rapid publication on acceptance

- support for research data, including large and complex data types

- gold Open Access which fosters wider collaboration and increased citations

- maximum visibility for your research: over $100 \mathrm{M}$ website views per year

At BMC, research is always in progress.

Learn more biomedcentral.com/submissions 